\title{
Analisa Faktor Eksternal yang Mempengaruhi Tingkat Return on Equity
}

\section{Ady Inrawan}

Sekolah Tinggi Ilmu Ekonomi Sultan Agung

ady@stiesultanagung.ac.id

\section{Hery Pandapotan Silitonga}

Sekolah Tinggi Ilmu Ekonomi Sultan Agung

hery@stiesultanagung.ac.id

\section{Acai Sudirman}

Sekolah Tinggi Ilmu Ekonomi Sultan Agung acaivenly@stiesultanagung.ac.id

\begin{abstract}
Abstrak The purpose of this study was to determine the effect of company external factors (inflation, interest rates, and exchange rates) on the ROE level. Associative research is used in this study with a qualitative approach. The object of research in companies of the Basic Industrial and Chemical Sub Sectors listed on the Indonesia Stock Exchange Period 2009 - 2018. Data collection techniques using the documentation method, data analysis techniques assumption of classiation, multiple linear regression, coefficient of determination and hypothesis testing. The results obtained, 1) Inflation, interest rates, exchange rates negatively affect $R O E, 2)$ inflation rates, interest rates, and exchange rates affect ROE of $91.8 \%, 3)$ F test results, Inflation Rates, Interest Rates, and Exchange Rates have a significant effect on ROE.
\end{abstract}

Kata Kunci Inflation, Interest Rates, Exchange Rates, ROE

\section{PENDAHULUAN}

Kelangsungan hidup perusahaan dalam menghadapi persaingan global saat ini, tergantung dari kemampuannya dalam menghasilkan keuntungan (Silitonga et al., 2017). Perusahaan harus memiliki kinerja yang baik, kinerja perusahaan tercermin dari laporan keuangannya pada suatu periode tertentu (Kartikasari \& Merianti, 2016). Kinerja keuangan perusahaan pencapaian bidang keuangan yang diperoleh manajemen dari kerja sama dan penggunaan dana secara efektif dan efesien.

Dengan kinerja yang baik akan terlihat dari kemampuannya dalam menghasilkan profit (Haque \& Rahmawati, 2017). Untuk memperoleh keuntungan yang maksimal perusahaan harus mengoptimalkan penggunaan modalnya (Khan et al., 2014). Profitabilitas merupakan rasio yang digunakan untuk mengukur kemampuan perusahaan dalam memperoleh keuntungan (Silitonga et al., 2017)(Jatiningtyas \& Iradianty, 2015). Return on equity (ROE) merupakan rasio yang digunakan untuk mengukur profitabilitas dalam penelitian ini. Salah satu jenis industri yang mengalami perkembangan yang cukup 
baik adalah industri dasar dan kimia. Berikut data perubahaan ROE pada perusahaan Manfaktur Sub Sektor Industri Dasar dan KimiaYang Terdaftar di BEI periode 20092018, sebagai berikut:

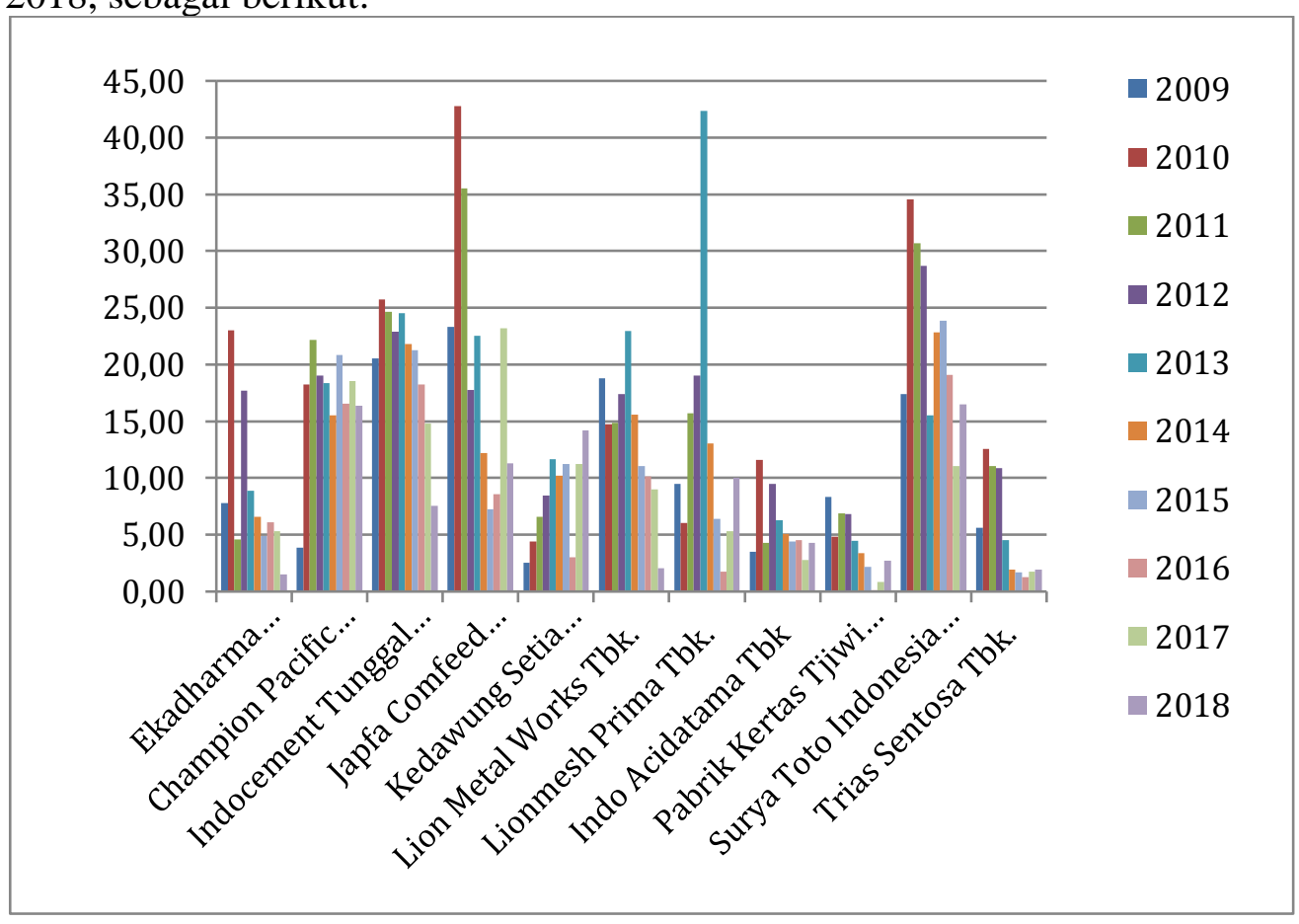

Gambar 1. Data Perubahaan ROE

ROE mengukur kinerja fundamental perusahaan dalam menggunakan sumber modal yang dimiliki untuk memperoleh keuntungan (Ashari \& Sampurno, 2017). Tinggi rendahnya nilai ROE dipengaruhi oleh faktor internal dan eksternal. Dalam penelitian ini yang menjadi fokus ialah faktor eksternal tersebut ialah inflasi, suku bunga, dan kurs. Kenaikan inflasi akan berdampak kepada kenaikan harga-harga yang signifikan secara terus menurus yang berlangsung dalam jangka waktu yang lama (Sasmita et al., 2019). Dengan tingkat inflasi yang tinggi akan mengakibatkan harga yang semakin mahal, hal ini kemuadian akan meningkatkan biaya yang dikeluarkan perusahaan untuk memperoleh bahan baku dan keuntungan perusahaan akan berkurang (Ifeanyi C. \& Chuskwuma C., 2016).

Tingkat suku bunga merupakan persentase uang pokok pada saat ini. Dengan tinggi nya tingkat suku bunga akan berdampak kepada perekonomian secara keseluruhan dikarena mempengaruhi kesediaan konsumen dan juga keputusan investasi oleh investor (Nurwita, 2019). Tingkat suku bunga merupakan hal yang penting dalam aktivitas perkenomian indonesia.bila suku bunga meningkat akan mengakibatkan cost menjadi tinggi, dimana hal ini akan memicu terjadinya inflasi, sehingga akan menurunkan tingkat keuntungan yang akan diperoleh perusahaan (Ridhwan, 2016).

Selain dua faktor eksternal di atas, nilai tukar juga mempengaruhi profitabilitas pada suatu perusahaan. Nilai tukar akan menentapkan return investasi yang nyata, dimana akan berdampak kepada penerimaan dan keuntungan yang akan diperoleh oleh perusahaan (Prastowo et al., 2014). Nilai tukar mencerminkan keseimbangan antara permintaan dan penawaran. Peningkatan inflasi akan melemahkan nilai tukar yang mengakibatkan harga 
saham akan turun (Isnurhadi et al., n.d.). Fenomena ini sangat tidak disukai investor dalam melakukan invesatsi yang berimbas perusahaan akan kekurangan pendanaan dalam menambah aktifitas nya. Profitabilitas merupakan hal yang sangat penting bagi perusahaan, karena untuk hal tersebut akan menarik investor dalam melakukan investasi. Berdasarkan penjelasan diatas maka penelitian ini bertujuan untuk mengetahui pengaruh faktor eksternal perusahaan (inflasi, suku bunga, dan nilai tukar) terhadap tingkat ROE.

\section{LANDASAN TEORI}

\section{Return On Equity (ROE)}

Keuntungan menjadi tujuan jangka pendek suatu perusahaan. Semakin tinggi tingkat keuntungan yang diperoleh oleh perusahaan maka semakin besar dana internal yang dimiliki, sehingga penggunaan utang akan semakin kecil. Semakin tinggi tingkat ROE perusahaan semakin tinggi persentase kinerja keuangan perusahaan tersebut (Inrawan et al., 2020). Investor menggunakan rasio ROE untuk mengukur keuntungan yang akan diperoleh yang akan dialokasikan kepada pemegang saham (Rosikah et al, 2018). Tingkat ROE digunakan untuk menentukan apakah manfaat yang dihasilkan cukup dengan modal yang diinvestasikan. ROE dapat dihitung menggunakan rumus, sebagai berikut:

$$
\text { Return On Equity }=\frac{\text { Laba Setelah Pajak }}{\text { Total Ekuitas }}
$$

\section{Inflasi}

Inflasi merupakan faktor fundamental makro serta indikator yang mencerminkan kondisi ekonomi yang tidak sehat akibat kenaikan harga barang secara umum yang membuat daya beli masayrakat menjadi melemah (Isnurhadi et al., n.d.). Kondisi inflasi membuat semua harga barang mengalam kenaikan dan mata uang mengalami pelemahaan. Jika inflasi tidak segera diatasi mengakibatkan memburuknya kondisi ekonomi secara keseluruhan (Hamidah et al., 2015). Inflasi menyebabkan terjadinya peningkatan harga barang, kenaikan harga upah, sehingga mengakibatkan harga pokok meningkat (Nurina, 2016). Untuk mengukur tingkat inflasi digunakan rumus, sebagai berikut:

$$
\mathrm{INFn}=\frac{I H K n-I H K n_{-1}}{I H K n_{-1}} \times 100 \%
$$

\section{Suku Bunga BI}

Tingkat suku bunga salah satu faktor eksternal yang mempengaruhi profitabilitas. Investor menggunakan infromasi suku bunga dalam melakukan investasi. Tingkat suku bunga merupakan dana yang tersedia untuk dipinjamkan atau yang sering disebut sebagai dana investasi (Setyaningsih, Aryani et al., 2018). Suku bunga dapat ditentukan dengan sertifikat Bank Indonesia dalam jangka waktu 1 bulan (Prastowo et al., 2014). Dengan peningkatan suku bunga menyebabkan tingkat pengembalian utang oleh perusahaan akan meningkat, hal ini menyebabkan penurunan profitabilitas yang diperoleh perusahaan (Zuchrinata \& Yunita, 2019). Tingkat suku bunga di pasar menentukan minat masyarakat dalam menentukan pilihan berinvestasi, alasannya karena investor akan melakukan 
investasi apabila keuntungan yang lebih besar daripada tingkat suku bunga yang harus dibayarkan untuk dana investasi (Iba \& Wardhana, 2012).

\section{Nilai Tukar}

Nilai tukar mengukur suatu mata uang dengan unit mata uang lainnya. Nilai tukar suatu nilai yang menunjukkan jumlah mata uang dalam negeri untuk memperoleh satu unit mata uang asing (Sasmita et al., 2019). Nilai tukar memberikan informasi untuk membandingkan imabalan yang ditawarkan oleh domestik setoran mata uang dan mata uang asing dengan perkiraan nilai tukar selama tahun tersebut (Kala et al., 2018). Beberapa faktor yang menyebabkan kenaikan nilai tukar adalah tingkat inflasi, tingkat suku bunga, tingkat pendapatan, pengendalian pasar, dan ekpektasi pasar (Iba \& Wardhana, 2012). Niali tukar diukur dalam persentase setiap periodenya (Prastowo et al., 2014).

\section{Faktor Eksternal Mempengaruhi ROE}

Faktor eksternal perusahaan yaitu inflasi, suku bunga, nili tukar mempengaruhi tingkat ROE perusahaan. Peningkatan inflasi yang tinggi akan menyebabkan daya beli masyarakat, sehingga mengurangi pendapat perusahaan. Namun jika inflasi diantisipasi maka semua suku bunga akan meningkat untuk menyertakan inflasi sebagai indikator peningkatan pendapatan lebih cepat dari biaya dan akan berdampak positif terhadap perofitabilitas perusahaan (Hamidah et al., 2015)(Iba \& Wardhana, 2012), (Kala et al., 2018). Peningkatan BI Rate mendorong peningkatan suku bunga, peningkatan tersebut meningkatkan suku bunga pinjaman yang harus dibayar perusahaan. Dengan demikian tingkat ROE perusahaan aka mengalami penurunan (Prastowo et al., 2014). Nilai tukar akan mempengaruhi hasil investasi dari dana yang investor. Mata uang yang menurun nilai tukarnya akan mengurangi daya beli investor dari pendapatan atas deviden, semakin tinggi nilai tukar akan mengurangi keuntungan yang akan diperoleh (Sasmita et al., 2019) dan (Setyaningsih, Aryani et al., 2018). Kerangka konseptual dalam penelitian ini, sebagai berikut:

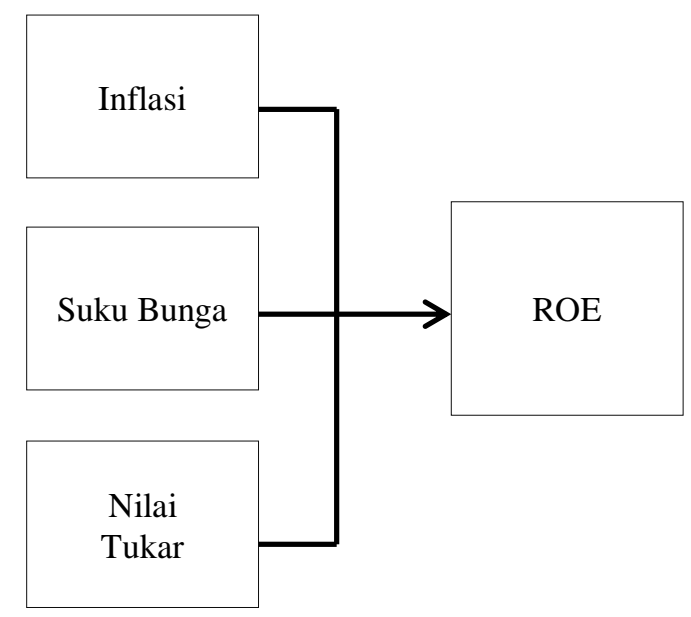

Gambar 2. Kerangka Konseptual

\section{METODOLOGI PENELITIAN}


Penelitian ini merupakan penelitian asosiatif, bertujuan untuk mengetahui apakah variabel dipengaruhi variabel lainnya atau variabel lain menjadi perubah variabel lainnya. Pendekatan penelitian mengunakan pendekatan kuantitatif. Objek penelitian pada perusahaan sub sektor Industri Dasar dan Kimia yang terdaftar di Bursa Efek Indonesia Periode 2009 - 2018. Populasi 52 perusahaan. Teknik sampel menggnakan purposive sampling, dengan menggunakan kriteria-kriteria yang dijadikan pertimbangan, sebagai berikut:

Tabel 1

Kriteria Penetuan Sampel

\begin{tabular}{|l|c|}
\hline \multicolumn{1}{|c|}{ Kriteria } & Jumlah \\
\hline Perusahaan pada sub sekotr industri dasar dan kimia & 52 \\
\hline $\begin{array}{l}\text { Perusahaan yang tidak menerbitkan laporan } \\
\text { keuangannya pada periode 2009-2018 }\end{array}$ & 27 \\
\hline $\begin{array}{l}\text { Perusahaan yang mengalami kerugian 3 tahun berturut- } \\
\text { turut selama periode peneltiian }\end{array}$ & 14 \\
\hline Sampel Penelitian & 11 \\
\hline
\end{tabular}

Sumber: Data Diolah (2020)

Setelah dilakukan pemilihan sampel menggunakan kriteria tersebut, maka sampel penelitian ini 11 perusahaan. Teknik pengumpulan data menggunakan metode dokumentasi melalui buku-buku, dan refrensi melalui media digital.

Teknik analisis data yang digunakan uji asumsi klasik, uji regresi linear berganda, koefesien determinasi, uji hipotesis.

\section{HASIL PENELITIAN}

\section{Uji Normalitas}

Hasil uji normlaitas mengggunakan kolmogorov-smirnov, sebagai berikut:

Tabel 2

Hasil Uji Normalitas

\begin{tabular}{|ll|r|}
\hline & & \multicolumn{2}{|c|}{ ROE } \\
\hline Normal Parameters & \\
& & 10 \\
& Mean & 13,6402 \\
Most Extreme & Std. Deviation & 4,01056 \\
Differences & Absolute &, 245 \\
& Positive &, 198 \\
Kolmogorov-Smirnov Z & Negative &,- 245 \\
Asymp. Sig. (2-tailed) & &, 774 \\
\hline
\end{tabular}

Sumber: Data Diolah (2020)

Dari tabel di atas diperoleh nilai Unstandardized Residualsebesar 0,587 > 0,05, artinya seluruh variabel dalam penelitian ini berditribusi normal.

\section{Uji Multikolineritas}


Uji multikolineritas menggunakan Varince Inflation Factor (VIF), sebagai berikut:

Tabel 3

Hasil Uji Multikolineritas

\begin{tabular}{|c|c|c|}
\hline \multirow[t]{2}{*}{ Model } & \multicolumn{2}{|c|}{ Collinearity Statistics } \\
\hline & Tolerance & VIF \\
\hline (Constant) & & \\
\hline Tingkat Inflasi & ,409 & 2,447 \\
\hline Suku Bunga & ,407 & 2,460 \\
\hline Nilai Tukar & ,990 & $\mathbf{1 , 0 1 0}$ \\
\hline
\end{tabular}

Sumber: Data Diolah (2020)

Dari tabel diatas diperoleh nilai VIF untuk seluruh variabel $<10$, artinya tidak terjadi gejala multikolineritas.

\section{Uji Heterokedasitas}

Uji heterokedasitas diuji menggunakan metode grafik, dengan hasil sebagai beriku:

scatterplot Dependent Variable: ROE

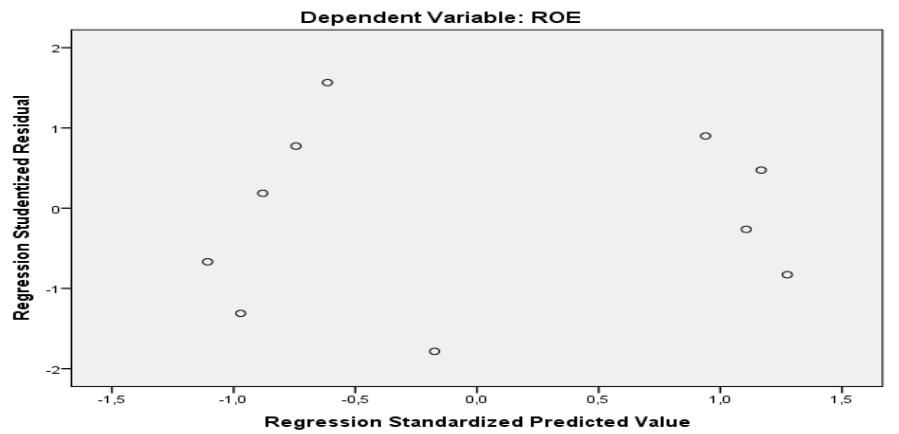

Gambar 3. Uji Heterokedasitas

Dari gambar grafik scatterplot diatas terlihat menyebar secara acak, maka dinyatakan tidak terjadi gejala heterokedastisitas.

\section{Uji Autokorelasi}

Uji autokorelasi menggunakan metode durbin watson, sebagai berikut:

\section{Tabel 4}

Uji Autokorelasi

\begin{tabular}{|l|lc|}
\hline Model & \multicolumn{2}{|c|}{ Durbin-Watson } \\
& & \\
\hline 1 & & $\mathbf{1 , 3 9 0}$ \\
\hline
\end{tabular}

a. Predictors: (Constant), NT, Tingkat.Inflasi, SB

b. Dependent Variable: ROE

Sumber: Data Diolah (2020)

Dari tabel $4 \mathrm{di}$ atas diperoleh nilai Durbin-Watson adalah 1,390. Pada Tabel Durbin-Watson dengan $\mathrm{n}=10$ dan $\mathrm{k}=3$, diperoleh nilai du sebesar 2,2866 dan 4-du $=4$ $1,5872=2,4128$, sedangkan nilai $\mathrm{dl}=0,3674$ dengan $4-\mathrm{dl}=2,6463$, dengan demikian nilai 
Durbin-Watsonberada pada $4-\mathrm{dU} \leq \mathrm{d} \leq 4-\mathrm{dL}$ atau $2,4128<2,596<2,6463$. Maka model persamaan regresi tersebut tanpa kesimpulan.

\section{Uji Regresi Linaer Berganda}

Untuk mengetahui pengaruh antar variabel digunakan analisis regresi linear berganda, hasilnya sebagai berikut:

Tabel 5

Uji Regrei Linear Berganda

\begin{tabular}{|l|r|r|r|}
\hline \multirow{2}{*}{ Model } & \multicolumn{2}{|c|}{ Unstandardized Coefficients } & \multicolumn{2}{c|}{$\begin{array}{c}\text { Standardized } \\
\text { Coefficients }\end{array}$} \\
\cline { 2 - 4 } & \multicolumn{1}{|c|}{ B } & Std. Error & \multicolumn{1}{c|}{ Beta } \\
\hline \multirow{2}{*}{ (Constant) } & $\mathbf{3 7 , 6 9 5}$ & 3,097 &,- 181 \\
Tingkat Inflasi & $\mathbf{- , 2 5 1}$ &, 207 &,- 012 \\
Suku Bunga & $\mathbf{- , 0 3 3}$ &, 403 &,- 967 \\
\hline
\end{tabular}

a. Dependent Variable: ROE

Sumber: Data Diolah (2020)

Berdasarkan tabel di atas, diperoleh model persamaan regresi, sebagai berikut:

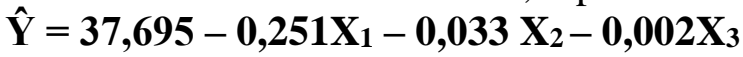

Persamaan regresi diperoleh hasil tingkat inflasi, suku bunga, nilai tukar berpengaruh negatif terhadap return on equity pada perusahaan Sub Sektor Industri Dasar dan Kimia periode 2009-2018.

\section{Koefesien Determinasi}

Hasil koefesien determinasi, sebagai berikut:

Tabel 5

Hasil Koefesien Determinasi

\begin{tabular}{|l|r|r|r|r|}
\hline Model & R & R Square & Adjusted R Square & $\begin{array}{c}\text { Std. Error of the } \\
\text { Estimate }\end{array}$ \\
\hline 1 &, $972^{\mathrm{a}}$ &, 945 & $\mathbf{9 1 8}$ & 1,15012 \\
\hline
\end{tabular}

Sumber: Data Diolah (2020)

Berdasarkan tabel di atas diperoleh nilai koefisien determinasinya (Adjusted $R$ square) sebesar 0,918atau 91,8\%, hal ini berarti Tinkat Inflasi, Suku Bunga, dan Nilai Tukar dapat mempengaruhi variabel ROE, dan sisanya 8,20\% dipengaruhi oleh variabel lain yang tidak dibahas dalam penelitian ini.

\section{Uji Hipotesis}

\section{Uji Simultan}

Besarnya pengaruh dari seluruh variabel independen secara simultan terhadap variabel dependen digunakan uji F. Hasil uji F, sebagai berikut:

\section{Tabel 6}




\begin{tabular}{|c|c|c|}
\hline & Hasil Uji F & \\
\hline Model & $\mathrm{F}$ & Sig. \\
\hline \begin{tabular}{|ll} 
& Regression \\
1 & $\begin{array}{l}\text { Residual } \\
\text { Total }\end{array}$
\end{tabular} & 34,479 &, $000^{b}$ \\
\hline
\end{tabular}

Sumber: Data Diolah (2020)

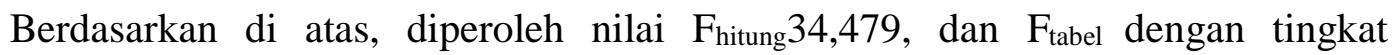
signifikan 5\%, n-k-1 atau 10-3-1=6 dengan diperoleh nilai 4,76. Hal ini menunjukkan bahwa $F_{\text {hitung }}(34,479)>F_{\text {tabel }}(4,76)$ atau tingkat signifikansi $0,000<0,05$, hal ini berarti Tingkat Inflasi, Suku Bunga, dan Nilai Tukar berpengaruh signifikan terhadap ROE.

\section{Uji Parsial}

Untuk mengetahui pengaruh masing-masing variabel digunakan uji t.Hasil uji t, sebagai berikut:

Tabel 7

Hasil Uji t

\begin{tabular}{|c|c|c|}
\hline Model & $\mathrm{t}$ & Sig. \\
\hline \begin{tabular}{|ll} 
& (Constant) \\
1 & Tingkat.Inflasi \\
Suku Bunga \\
Nilai Tukar
\end{tabular} & $\begin{array}{r}12,171 \\
-\mathbf{1 , 2 1 1} \\
-\mathbf{0 0 8 1} \\
\mathbf{- 1 0 , 0 6 5}\end{array}$ & $\begin{array}{l}, 000 \\
, 271 \\
\mathbf{9 3 8} \\
\mathbf{0 0 0}\end{array}$ \\
\hline
\end{tabular}

Sumber: Data Diolah (2020)

Berdasarkan hasil uji $t$, diperoleh $t_{\text {tabel }}$ sebesar 1,895, maka pengaruh tiap-tiap variabel independen, sebagai berikut:

1. Tingkat Inflasi, dengan $t_{\text {hitung }}$ sebesar $-1,211$, dan nilai signifikan $0,271>0,05$, artinya Tingkat Inflasi berpengaruh negatif dan tidak signifikan terhadap ROE.

2. Tingkat Suku Bunga, dengan $t_{\text {hitung }}$ sebesar $-0,081$, dan nilai signifikan 0,938>0,05, artinya Suku Bunga berpengaruh negatif dan tidak signifikan terhadap ROE

3. Tingkat Nilai Tukar, dengan $t_{\text {hitung }}$ sebesar $-10,065$, dan nilai signifikan $0,00<0,05$, artinya Nilai Tukar berpengaruh negatif dan signifikan terhadap ROE.

\section{Pembahasan}

Faktor eksternal perusahaan mempengaruhi return on equity perusahaan. Model

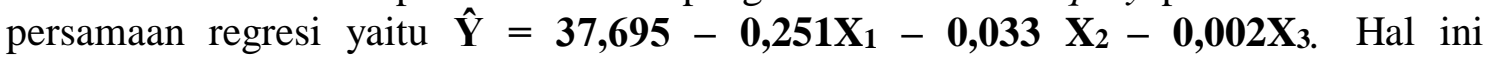
diinterprestasikan sebagai berikut

1. Konstanta senilai 37,695 dengan arah hubungan positif artinya bila nilai inflasi, suku bunga, dan nilai tukar konstan makan nilai ROE sudah terbentuk sebesar 37,695.

2. Inflasi sebesar 0,251 dengan arah hubungan negatif artinya jika inflasi meningkat satu satuan maka nilai ROE akan mengalami penurunan sebesar 0,251. Inflasi yang tinggi mengakibatkan peningkatan harga barang-barang, hal ini membuat minat konsumen untuk memblei mengalami penurunan. Hal ini akan menurunkan jumlah keuntungan yang akan diperoleh perusahaan. Hasil ini sejalan dengan penelitian yang 
dilakukan (Setyaningsih, Aryani et al., 2018), (Zuchrinata \& Yunita, 2019), dan (Ifeanyi C. \& Chuskwuma C., 2016).

3. Suku bunga sebesar 0,033 dengan arah hubungan negatif, artinya bila suku bunga satu satuan mengalami peningkatan maka ROE perusahaan akan mengalami penurunan sebesar 0,033. Peningkatan suku bunga akan mengakibatkan peningkatkan suku bunga kredit. Hal ini mengakibatkan peningkatan beban yang harus dibayarkan perusahaan yang menurunkan tingkat keuntungan yang akan diperoleh perusahaan. Hal ini sejalan dengan penelitian yang dilakukan (Sasmita et al., 2019), (Zuchrinata \& Yunita, 2019), (Prastowo et al., 2014), dan (Ridhwan, 2016).

4. Nilai Tukar sebesar 0,002 dengan arah hubungan negatif, artinya jika nilai tukar mengalami kenaikan sebesar satu satuan maka ROE akan mangalami penurunan sebesar 0,002. Peningkatan nilai tukar mengakibatkan melemahnya nilai tukar rupiah mengakibatkan perusahaan akan mengurangi ekspor, dan mengakibatkan tingkat keuntungan perusahaan akan berkurang, dan biaya pinjaman yag meningkat dan membuat ROE mengalami penurunan. Hal ini sejalan dengan penelitian yang dilakukan (Ridhwan, 2016), (Prastowo et al., 2014), (Haque \& Rahmawati, 2017), dan (Sasmita et al., 2019).

Hasil koefisien determinasi 91,8\%, hal ini berarti Tinkat Inflasi, Suku Bunga, dan Nilai Tukar dapat mempengaruhi variabel ROE, dan sisanya 8,20\% dipengaruhi oleh variabel lain. Hasil uji simultan bahwa Tingkat Inflasi, Suku Bunga, dan Nilai Tukar berpengaruh signifikan terhadap ROE.

\section{KESIMPULAN}

Berdasarkan hasil penelitian yang telah dijabarkan sebelumnya, maka disimpulkan sebagai berikut:

1. Tingkat inflasi, suku bunga, dan niali tukar mempengaruhi ROE sebesar $91,8 \%$

2. Peningkatan inflasi akan menurunkan tingkat ROE perusahaan.

3. Suku bunga yang tinggi akan mengakibatkan penurunan ROE.

4. Nilai tukar yang meningkatkan akan menurunkan ROE.

5. Tingkat Inflasi, Suku Bunga, dan Nilai Tukar berpengaruh signifikan terhadap ROE.

\section{DAFTAR PUSTAKA}

Ashari, M. H., \& Sampurno, R. D. (2017). Pengaruh Utang Terhadap Profitabilitas Pada Perusahaan Food \& Beverage Yang Terdaftar Di Bursa Efek Indonesia Periode 2011-2015. Jurnal Riset Akuntansi Dan Keuangan, 5(1), 1-12. https://doi.org/10.17509/jrak.v5i1.6729

Hamidah, H., Hartini, H., \& Mardiyati, U. (2015). Pengaruh Inflasi, Suku Bunga Bi,Profitabilitas, Dan Risiko Finansial Terhadap Nilai Perusahaan Sektor Properti Tahun 2011-2013. JRMSI - Jurnal Riset Manajemen Sains Indonesia, 6(1), 395. https://doi.org/10.21009/jrmsi.006.1.04 
Haque, H. M., \& Rahmawati, R. (2017). Pengaruh Nilai Tukar Mata Uang dan Inflasi terhadap Profitabilitas di Bank Syariah: Studi Analisis pada Bank Muamalat, Bank Mandiri Syariah dan Bank Mega Syariah Periode 2011-2015. 8(1), 69-92.

Iba, Z., \& Wardhana, A. (2012). Pengaruh Inflasi, Suku Bunga Sbi, Nilai Tukar Rupiah Terhadap Usd, Profitabilitas, Dan Pertumbuhan Aktiva Terhadap Harga Saham Perusahaan Pembiayaan Di Bursa Efek Indonesia. Jurnal Kebangsaan, 1(1), 1-6.

Ifeanyi C., N., \& Chuskwuma C., U. (2016). An Empirical Analysis of Inflationary Impacts on Profitability and Value of Selected Manufacturing Firms in Nigeria. Research Journal of Finance and Accounting, 7(12), 19-26.

Inrawan, A., Jubi, Silitonga, H. P., \& Sudirman, A. (2020). PENGARUH LIKUIDITAS DAN SOLVABILITAS TERHADAP RENTABILITAS MODAL SENDIRI PADA PKPRI DI KABUPATEN SIMALUNGUN. 5(1), 1-15.

Isnurhadi, H., Taufik, H., \& Herwanto, D. (n.d.). The Effect of Macroeconomic Fundamental Factors On Corporate Value Through Financial Performance As Intervening Variables In Manufacturing Companiesn In Indonesia Stock Exchange. $1-26$.

Jatiningtyas, N., \& Iradianty, A. (2015). The Effect Inflation, Interest Rate, Exchange Rate, Return on Assets ( ROA ), and Debt Ratio ( DER ) on Stock Return (Case Study on Telecommunication Subsector Listed in Indonesia Stock Exchange Period.

Kala, G., Masbar, R., \& Syahnur, S. (2018). The Effect of Exchange Rate, Inflation, Capital and Labor Force on Economic Growth in Indonesia. Jurnal Ekonomi Dan Kebijakan Publik Indonesia, 5(1), 35-50.

Kartikasari, D., \& Merianti, M. (2016). The effect of leverage and firm size to profitability of public manufacturing companies in Indonesia. International Journal of Economics and Financial Issues, 6(2), 409-413.

Khan, S., Malik, M. F., Khan, M. I., \& Khan, F. (2014). Interest Rate and Its Effect on Bank's Profitability. J. Appl. Environ. Biol. Sci. Journal of Applied Environmental and Biological Sciences, 4(8S), 225-229. www.textroad.com

Nurina, S. (2016). Analisis Pengaruh Inflation, Interest Rate, Dan Exchange Rate Terhadap Gross Domestic Product (Gdp) Di Indonesia. Analisis Pengaruh Inflation, Interest Rate, Dan Exchange Rate Terhadap Gross Domestic Product (Gdp) Di Indonesia, 2(1), 1-18.

Nurwita. (2019). PENGARUH RASIO HUTANG, STRUKTUR KEPEMILIKAN, SUKU BUNGA, INFLASI DAN PROFITABILITAS TERHADAP PRICE EARNING RATIO PADA PERUSAHAN LQQ -, 45 PERIODE 2011 - 2014. 2(3), 141-160.

Prastowo, P. R., Malavia, R., \& Wahono, B. (2014). Analisis Pengaruh Inflasi, Suku Bunga dan Nilai Tukar Terhadap Profitabilitas Perbankan. E - Jurnal Riset Manajemen PRODI MANAJEMEN, 27-41. http://riset.unisma.ac.id/index.php/jrm/article/download/1324/1322

Ridhwan. (2016). Analisis Pengaruh Suku Bunga dan Inflasi Terhadap Profitabilitas PT Bank Syariah Mandiir Indonesia. In Jurnal Penelitian Universitas Jambi Seri Humaniora (Vol. 18, Issue 2).

Rosikah et al. (2018). Effects of Return on Asset, Return On Equity, Earning Per Share on Corporate Value. The International Journal of Engineering and Science (IJES, 7(3), 6-14. https://doi.org/10.9790/1813-0703010614

Sasmita, D., Andriani, S., \& Ilman, A. H. (2019). ANALISIS PENGARUH INFLASI, SUKU BUNGA BI, NILAI TUKAR RUPIAH TERHADAP PROFITABILITAS 
(STUDI KASUS PADA BANK YANG TERDAFTAR DI BEI PERIODE 2011 2015). Jurnal Ekonomi Dan Bisnis Indonesia, 3(1), 1-7.

Setyaningsih, Aryani, C., Sriwidodo, U., \& Utami, Sri, S. (2018). Analisis pengaruh suku bunga, inflasi, dan nilai tukar rupiah terhadap profitabilitas bank umum swasta nasional di bursa efek indonesia. Jurnal Ekonomi Dan Kewirausahaan, Vol. 18 No, 323-331.

Silitonga, H. P., Siregar, L., Tarigan, P., \& Inrawan, A. (2017). PENGARUH LIKUIDITAS DAN LEVERAGE TERHADAP PROFITABILITAS PADA PT JAPFA COMFEED INDONESIA , Tbk . YANG TERDAFTAR DI BURSA EFEK INDONESIA. 3(1), 1-9.

Zuchrinata, F. A., \& Yunita, I. (2019). Pengaruh Inflasi, Suku Bunga Bank Indonesia, Debt to Equity Ratio, Ukuran Perusahaan dan Umur Perusahaan terhadap profitabilitas Perusahaan Sub Sektor Pertambanagan Batubara yang Terdaftar di BEI Tahun 2013-2017. JIM UPB (Jurnal Ilmiah Manajemen Universitas Putera Batam), 7(2), 189. https://doi.org/10.33884/jimupb.v7i2.1232 